\title{
Seropositive Form of Occult Hepatitis B Virus Infection in Iranian Patients with Cryptogenic Liver Cirrhosis
}

\author{
Javad Moayedi ${ }^{1,2}$, Maryam Moini ${ }^{3}$, Bita Geramizadeh ${ }^{1}$, Seyed Ali Malekhosseini ${ }^{1}$ and Ramin \\ Yaghobi ${ }^{1, *}$ \\ ${ }^{1}$ Shiraz Transplant Research Center, Shiraz University of Medical Sciences, Shiraz, Iran \\ ${ }^{2}$ Department of Microbiology, Jahrom Branch, Islamic Azad University, Jahrom, Iran \\ ${ }^{3}$ Department of Internal Medicine, School of Medicine, Shiraz University of Medical Sciences, Shiraz, Iran \\ "Corresponding author: Shiraz Transplant Research Center, Shiraz University of Medical Sciences, Shiraz, Iran. Email: rayaviro@yahoo.com
}

Received 2018 September 30; Revised 2019 March 05; Accepted 2019 March 10.

\begin{abstract}
Background: The causes of cryptogenic cirrhosis, as one of the most important unresolved issues in the management of liver failure, remains unknown. Hepatitis B virus (HBV) infection with a high impact in Iranian liver graft recipients may have a key role in introducing and developing cryptogenic cirrhosis, especially in the occult form. Therefore, the prevalence of occult HBV infection was evaluated in liver transplant recipients with cryptogenic cirrhosis.

Methods: In this cross-sectional study, a total of 127 liver transplant recipients with cryptogenic cirrhosis were recruited. The serum samples of patients were evaluated for immunological HBV infective markers, using enzyme-linked immune sorbent assay (ELISA) methods. Moreover, immunohistochemistry (IHC) was used for detection of HBsAg in liver tissue sections. Collected serums and liver tissue samples were also examined for HBV genomic DNA, using a qualitative polymerase chain reaction (PCR) technique.

Results: HBsAg was not found in any studied liver tissue or serum samples. However, HBV genomic DNA was found in the liver tissue and serum samples of $35.4 \%$ and $36.2 \%$ of the liver transplant patients with cryptogenic cirrhosis, respectively. Occult HBV infection was found in $35.4 \%$ of the patients with cryptogenic cirrhosis. Seropositive and seronegative types of occult HBV infection were found in $82.2 \%$ and $17.8 \%$ of the patients, respectively.

Conclusions: Findings of the high prevalence of molecular and immunological markers of HBV infection, especially occult ones, in liver transplanted patients with cryptogenic cirrhosis was re-enforced. These results indicate the important role of occult HBV infection in the pathogenesis of cryptogenic cirrhosis, which needs to be evaluated in the future through comprehensive studies.
\end{abstract}

Keywords: Hepatitis B Virus, Cryptogenic Cirrhosis, Occult Infection, Liver Transplantation

\section{Background}

Cryptogenic cirrhosis refers to liver cirrhosis with uncertain etiology that lacks definitive clinical and histological criteria for a specific disease (1). Cryptogenic cirrhosis represents a significant proportion of end-stage chronic liver disorders and is currently considered as one of the most important indications of orthotopic liver transplantation (OLT), worldwide (2,3). Although recent advances allowed a more clear understanding of the cause of liver disorders, the etiology of cryptogenic cirrhosis remains unknown, even after improvement of the laboratory, clinical, and pathologic analyses. It has been estimated that up to $30 \%$ of cirrhotic cases and about $10 \%$ of liver transplant underlying diseases remained cryptogenic $(4,5)$. Viral hepatitis has been suggested as the potential cause of cryptogenic cirrhosis. Hepatitis B virus (HBV) and hepatitis C virus (HCV) infections were the most common cause of viral chronic liver diseases, chronic hepatitis, and cirrhosis in an endemic area (6-11).

Diagnosis and disappearance of hepatitis B surface antigen (HBsAg) usually indicates the presence or clearance of HBV infection, yet it has been shown that some patients may have a persistent viral infection, while HBsAg is negative $(12,13)$. Occult HBV infection is defined as persistence of HBV genomic DNA in liver tissues with or without serums of patients serologically undetectable for HBsAg $(14,15)$. The reason for the lack of HBsAg in occult HBV infection is unclear. In other words, about $20 \%$ of occult HBV-infected patients were negative for all of the serum markers of HBV infection (16). Mechanisms, such as mutations in HBV genomic regulatory regions, integration of HBV genomic DNA in the host's chromosomes, infectivity of peripheral blood mononuclear cells (PBMCs), alteration 
of the host immune response, and the interference of the other viruses in HBV pathogenesis have been proposed as the possible reason of occult infections (17-19).

Diagnosis of occult HBV infection was based on sensitive polymerase chain reaction (PCR) assays, which could be able to detect HBV genomic DNA at less than 104 copies/mL $(17,19,20)$. The prevalence of occult HBV infection in cirrhotic patients was affected with two parameters: The prevalence of HBV infection in the population and sensitivity of the assays, which were used to detect HBV genomic DNA (19-21). Occult HBV infection has a worldwide spread and seems to be found in up to $71 \%$ of liver tissues and $55 \%$ of sera from HBsAg negative patients $(13,20,22)$. The prevalence of $\mathrm{HBV}$ infection in the Iranian population varied from $2.7 \%$ to $7.2 \%$, yet it decreased to lower than $2 \%$ after the national vaccination program $(22,23)$.

However, the prevalence of occult HBV infection in Iranian patients with cryptogenic cirrhosis was high $(24,25)$. By accepting the fact that HBV infection is common among Iranian patients with end-stage liver disease, and a proportion of these patients with the cryptogenic liver disorder may have occult HBV infection (26), it is reasonable to screen cryptogenic cirrhotic patients for the occult form of HBV.

\section{Objectives}

Therefore, the present study aimed at evaluating the prevalence of occult types of chronic HBV infection in liver transplant recipients with cryptogenic cirrhosis.

\section{Methods}

\subsection{Patients and Samples}

A total of 127 liver transplant patients, who were admitted to organ transplant unit, Namazi Hospital affiliated to Shiraz University of Medical Sciences, Shiraz, Iran, were recruited in this cross-sectional study during years 2007 to 2011. The etiology of liver cirrhosis was evaluated and confirmed using clinical, laboratory, and histological analysis. Patients with defined etiology for the underlying disease of liver cirrhosis were ruled out, and patients labeled with cryptogenic cirrhosis, especially negative for routine HBV, $\mathrm{HCV}$, and human immunodeficiency virus (HIV) infections, were included in this study. The EDTA-treated blood and paraffin-embedded liver tissue samples that were already collected form liver transplanted patients and saved in the sample bank of the Pathology Laboratory of Namzi Hosipital and Shiraz Transplant Research Center, Shiraz University of Medical Sciences Shiraz, Iran, were used for molecular, serological, and pathological evaluations. The study protocol was approved by the Medical Ethics Committee of Shiraz University of Medical Sciences.

\subsection{Molecular Analysis}

The HBV genomic DNA was extracted from the serum and paraffin-embedded formalin fixed liver tissue samples using the DNP kit (CinnaGene Inc, Iran), according to the manufacturer's instructions. Presence of the HBV genomic DNA was analyzed using a qualitative HBV-PCR detection kit (CinnaGene Inc, Iran). The PCR product (353 bp) was analyzed by electrophoresis on $1 \%$ agarose gel.

\subsection{Immunological Analysis}

The HBV antigens and antibodies including HBsAg, hepatitis B envelope antigen (HBeAg), hepatitis B surface antigen antibody (HBsAb), hepatitis B core antibody (HB$\mathrm{cAb}$ ), and hepatitis B surface envelope antibody (HBeAb), were evaluated using third generation enzyme linked immunosorbent assay (ELISA) kits (Dia.Pro, Italy), according to the manufacturer's instructions.

\subsection{Pathological Analysis}

Immunohistochemistry was performed for detection of HBsAg in liver tissue sections using highly specific anti-HBs mAb (Dako, Denmark) as follows: Serial sections with $3 \mu \mathrm{m}$ thicknesses were obtained from each paraffinembedded liver tissue specimen and mounted on polyL lysine coated slides. Immunohistochemistry was performed on selected paraffin blocks of each case using streptavidin-biotin-peroxidase complex detection system (LSAB kit, Dako, Denmark) with the presence of adequate and appropriate positive and negative controls. For negative controls, all steps of the procedure were performed without primary antibodies.

\subsection{Statistical Analysis}

The possible statistical associations were evaluated using the Statistical Package for Social Sciences (SPSS), version 15 . The quantitative data were expressed as mean \pm standard deviation (SD) and comparisons between the categorical variables were performed using the Pearson chisquare or Fisher's exact test. A P value of less than 0.05 was considered to be statistically significant.

\section{Results}

A total of 80 (63\%) males and $47(37 \%)$ females (male/female ratio 1.7) with an age range of 4 to 67 years old (mean $34.9 \pm 15.9$ ) were enrolled. The rejection rate was $8.7 \%$ and 10 (7.9\%) patients were expired within the 
first months of transplantation. There was a strong association $(\mathrm{P}<0.0001)$ between graft rejection and expiration rate. Among the eleven patients, who experienced acute rejection, seven (63.6\%) patients were dead. Data of blood grouping, experience of acute rejection, and expiration of recipient are presented in Table 1.

\begin{tabular}{lc}
\hline $\begin{array}{c}\text { Table 1. Demographic Characteristics in Liver Transplanted Patients with Crypto- } \\
\text { genic Cirrhosis }\end{array}$ \\
\hline Parameter & Values \\
\hline Blood groups & \\
\hline O+ & $41(32.3)$ \\
\hline O- & $5(3.9)$ \\
\hline A+ & $32(25.2)$ \\
\hline A- & $2(1.6)$ \\
\hline B+ & $30(23.6)$ \\
\hline B- & $3(2.4)$ \\
\hline AB+ & $14(11)$ \\
\hline AB- & $0(0)$ \\
\hline Acute rejection & $11(8.7)$ \\
\hline Expired & $10(7.9)$ \\
\hline
\end{tabular}

${ }^{\mathrm{a}}$ Values are expressed as No. (\%).

\subsection{Hepatitis B Virus Infective Markers in Patients with Crypto- genic Cirrhosis}

The HBV genomic DNA was detected in 45 (35.4\%) and 46 (36.2\%) liver tissue and serum samples, respectively. However, HBsAg was not detected in the liver tissue and serum samples of any studied patient. The results of other HBV immunological markers were also as follows: HBeAg (24.4\%), anti-HBe (0.8\%), anti-HBc (4.7\%), and antiHBs (61.4\%).

\subsection{Occult Hepatitis B Virus Infection}

Evaluation of the HBsAg negative patients with detectable HBV genomic DNA in liver tissue samples confirmed that $35.4 \%$ ( 45 out of 127 ) of patients had occult HBV infection. These patients were classified to two groups of seropositive (37 out of $45,82.2 \%$ ) and seronegative ( 8 of 45 , $17.8 \%$ ) based on the presence or absence of anti-HBc and/or anti-HBs antibodies in serum samples. In seronegative occult HBV-infected patients, all of the HBV immunologic markers were undetectable. The prevalence of HBV infective markers in patients with seropositive and seronegative occult HBV infection is presented in Table 2.

\subsection{Occult Hepatitis C Virus Infection}

The liver tissue specimens of cryptogenic patients with occult HBV infection were also evaluated for occult HCV infection. Genomic HCV-RNA was found in four out of 45 (8.9\%) patients, who were labeled as having seropositive occult HBV infection.

\section{Discussion}

Cryptogenic cirrhosis, which is a type of liver cirrhosis with no readily identifiable cause and etiology, is found in about $10 \%$ of patients on the waiting list for liver transplantation (2-4). When the cause of liver cirrhosis is unknown, it is very difficult to control progression and treatment of the liver complicated disorder, leading to decompensation of liver damage and increased need of transplantation (2). Hepatitis B virus is an important etiological agent for liver cirrhosis, ranging between $0.1 \%$ to $15 \%$ in the healthy population reported from different countries $(2,27)$. It has been estimated that up to $40 \%$ of patients with liver cirrhosis are HBV-infected individuals (28). In addition, the occult form of HBV infection, which is a type of HBV infection and suffers from diagnostic complication was found in up to $60 \%$ of cirrhotic patients, worldwide (29).

In the present study, cryptogenic cirrhosis was found more commonly in male recipients (63\%); this is compatible with the findings of previous studies $(22,30,31)$ yet in disagreement with others $(32,33)$. As expected, HBsAg was not detected in patients with cryptogenic cirrhosis. In a recent study from Iran, Hashemi et al. (22) detected a lower rate of anti-HBs (24\%) and a higher rate of anti-HBc (20\%) antibodies in the serums of cryptogenic patients. Chan et al. (13) detected anti-HBs and/or anti-HBc antibodies in $89 \%$ and $92 \%$ of patients with cryptogenic liver cirrhosis, respectively. In this study, anti-HBS and anti-HBc antibodies were found in the serums of $61.4 \%$ and $4.7 \%$ of patients with cryptogenic cirrhosis, respectively. Moreover, unexpected higher frequency of HBeAg (24.4\%) and lower frequency of anti-HBe (0.8\%) antibody was found in the studied patients. The higher rate of HBeAg in patients with cryptogenic cirrhosis could be considered as an active infection.

Surprisingly, HBV gnomic DNA was found with higher prevalence in liver tissue and serum samples of patients with cryptogenic cirrhosis. Although HBV genome could be detectable in the serums of $5 \%$ to $76 \%$ of patients with cryptogenic cirrhosis (34), in this study, 36.2\% of HBsAg negative patients had detectable HBV genomic DNA in their serums, which is higher than that reported in a previous report (14\%) from Iran (22) and that reported in Israeli patients (13). 


\begin{tabular}{|c|c|c|c|}
\hline \multirow[t]{2}{*}{ HBV Infective Markers } & \multicolumn{3}{|c|}{ Patients with Occult HBV Infection } \\
\hline & Seropositive, $\mathbf{N}=37$ & Seronegative, $\mathbf{N}=\mathbf{8}$ & Total, $\mathrm{N}=\mathbf{4 5}$ \\
\hline \multicolumn{4}{|l|}{ Serum } \\
\hline HBsAg & $0(0)$ & $0(0)$ & $0(0)$ \\
\hline Anti-HBs & $37(100)$ & $0(0)$ & $37(82.2)$ \\
\hline Anti-HBc & $4(10.8)$ & $0(0)$ & $4(8.9)$ \\
\hline HBeAg & $9(24.3)$ & $0(0)$ & $9(20)$ \\
\hline Anti-HBe & $0(0)$ & $0(0)$ & $0(0)$ \\
\hline HBV-DNA & $16(43.2)$ & $3(37.5)$ & $19(42.2)$ \\
\hline \multicolumn{4}{|l|}{ Liver } \\
\hline HBsAg & $0(0)$ & $0(0)$ & $0(0)$ \\
\hline HBV-DNA & $37(100)$ & $8(100)$ & $45(100)$ \\
\hline
\end{tabular}

Abbreviations: HBV, hepatitis B virus; HBcAb, hepatitis B core antibody; HBeAg, hepatitis B envelope antigen; HBsAg, hepatitis B surface antigen

${ }^{\mathrm{a}}$ Values are expressed as No. (\%).

Occult HBV infection can reactivate in liver recipients after induction of immunosuppressive regimens, posttransplantation $(29,35)$. Occult or silent HBV infection is classified to seropositive and seronegative forms based on diagnosis or not finding of the anti-HBc and/or antiHBs antibodies, respectively $(25,29)$. The seropositive and seronegative forms of occult $\mathrm{HBV}$ infection can transmit from liver organ donors to recipients $(29,36)$. In this study, occult HBV infection was also found in $35.4 \%$ of the patients with cryptogenic cirrhosis. Seropositive and seronegative types of occult HBV infection were found in $82.2 \%$ and $17.8 \%$ patients, respectively. In concordance with the results of this study, earlier reports have shown occult HBV infection (especially in the seronegative type) in $19 \%$ to $30 \%$ of patients with cryptogenic liver cirrhosis $(26,37,38)$. In China and India, occult HBV infection in patients, who were labeled with cryptogenic cirrhosis, was reported up to $37 \%$ and $38 \%$, respectively $(13,39)$. Two recent studies on Iranian patients with cryptogenic cirrhosis also showed occult $\mathrm{HBV}$ infection in $14 \%$ and $38 \%$ of cases, respectively (22, 25). In addition, Honarkar et al. also found occult HBV infection in $22 \%$ of patients with liver cirrhosis (24).

In disagreement with the results of this study, Kaviani et al. (40) reported that $1.9 \%$ of patients with cryptogenic chronic hepatitis were infected with occult HBV. Moreover, Ferrari et al. (21) diagnosed occult HBV infection in only $4.4 \%$ of Brazilian cirrhotic patients undergoing liver transplantation. Surprisingly, Heringlake et al. (41) did not find any occult HBV infection among German patients. In contrast to a previous report from Iran that showed a higher rate of occult $\mathrm{HBV}$ infection among patients above 40 years (22), the current study indicated that age of patients did not alter the rate of occult $\mathrm{HBV}$ infection.

In conclusion, the high prevalence of occult HBV infection, especially the seropositive type, was found in Iranian liver transplant patients with cryptogenic cirrhosis. The current report presents the importance and determinative role of occult HBV infection in the pathogenesis of cryptogenic cirrhosis that needs to be confirmed in future studies, including larger populations with longer duration.

\section{Acknowledgments}

The authors acknowledge the personnel of Shiraz Transplant Research Center and also Research Consultation Center (RCC) of Shiraz University of Medical Sciences for their valuable assistance in editing this article.

\section{Footnotes}

Authors' Contribution: Study concept and design: Javad Moayedi, Maryam Moini, Bita Geramizadeh, Seyed Ali Malekhosseini, and Ramin Yaghobi. Analysis and interpretation of data: Javad Moayedi, Maryam Moini, and Ramin Yaghobi. Drafting of the manuscript: Javad Moayedi, Maryam Moini, and Ramin Yaghobi. Critical revision of the manuscript for important intellectual content: Javad Moayedi, Maryam Moini, and Ramin Yaghobi. Statistical analysis: Javad Moayedi and Ramin Yaghobi.

Conflict of Interests: The authors had no conflict of interests to declare.

Ethical Considerations: In this study blood and paraffinembedded liver tissue samples were used that already collected and saved in the sample bank of the Pathology Lab- 
oratory of Namzi Hosipital and Shiraz Transplant Research Center, Shiraz University of Medical Sciences Shiraz, Iran.

Funding/Support: This study was financially supported by grant No.: 87-100 from the Transplant Research Center of Shiraz University of Medical Sciences, Shiraz, Iran.

\section{References}

1. Yaghobi R, Kazemi MJ, Geramizadeh B, Malek Hosseini SA, Moayedi J. Significance of occult hepatitis $C$ virus Infection in liver transplant patients with cryptogenic cirrhosis. Exp Clin Transplant. 2018. doi: 10.6002/ect.2017.0332. [PubMed: 30346262].

2. Desai HG. Cryptogenic cirrhosis: A vanishing entity.J Assoc Physicians India. 2009;57:751-4. 759. [PubMed: 20329442].

3. Alamo JM, Bernal C, Barrera L, Marin LM, Suarez G, Serrano J, et al. Liver transplantation in patients with cryptogenic cirrhosis: Long-term follow-up. Transplant Proc. 2011;43(6):2230-2. doi: 10.1016/j.transproceed.2011.05.017. [PubMed: 21839241].

4. Marmur J, Bergquist A, Stal P. Liver transplantation of patients with cryptogenic cirrhosis: Clinical characteristics and outcome. Scand J Gastroenterol. 2010;45(1):60-9. doi: 10.3109/00365520903384742. [PubMed: 20030578].

5. Keyvani H, Bokharaei-Salim F, Monavari SH, Esghaei M, Nassiri Toosi M, Fakhim S, et al. Occult hepatitis C virus infection in candidates for liver transplant with cryptogenic cirrhosis. Hepat Mon. 2013;13(8). e11290. doi: 10.5812/hepatmon.11290. [PubMed: 24082889]. [PubMed Central: PMC3785931].

6. Sarma MP, Asim M, Medhi S, Bharathi T, Diwan R, Kar P. Viral genotypes and associated risk factors of hepatocellular carcinoma in India. Cancer Biol Med. 2012;9(3):172-81. doi: 10.7497/j.issn.20953941.2012.03.004. [PubMed: 23691475]. [PubMed Central: PMC3643662].

7. Michitaka K, Nishiguchi S, Aoyagi Y, Hiasa Y, Tokumoto Y, Onji M, et al. Etiology of liver cirrhosis in Japan: A nationwide survey. J Gastroenterol.2010;45(1):86-94. doi:10.1007/s00535-009-0128-5. [PubMed: 19789837].

8. Behzad-Behbahani A, Mojiri A, Tabei SZ, Farhadi-Andarabi A, Pouransari R, Yaghobi R, et al. Outcome of hepatitis B and C virus infection on graft function after renal transplantation. Transplant Proc. 2005;37(7):3045-7. doi: 10.1016/j.transproceed.2005.07.039. [PubMed: 16213299].

9. Ghanbari R, Ravanshad M, Hosseini SY, Yaghobi R, Shahzamani K. Genotyping and infection rate of GBV-C among Iranian HCV-infected patients. Hepat Mon. 2010;10(2):80-7. [PubMed: 22312378]. [PubMed Central: PMC3270361].

10. Kazemi MJ, Yaghobi R, Iravani Saadi M, Geramizadeh B, Moayedi J. Association between TT virus Infection and cirrhosis in liver transplant patients. Hepat Mon. 2015;15(9). e28370. doi: 10.5812/hepatmon.28370. [PubMed: 26504468]. [PubMed Central: PMC4612723].

11. Janfeshan S, Yaghobi R, Eidi A, Karimi MH, Geramizadeh B, Malekhosseini SA, et al. Study the cross-talk between hepatitis B virus Infection and Interferon regulatory factors in liver transplant patients. Hepat Mon. 2017;17(11). e12426. doi: 10.5812/hepatmon.12426.

12. Kao JH, Chen PJ, Lai MY, Chen DS. Occult hepatitis B virus infection and clinical outcomes of patients with chronic hepatitis C.J Clin Microbiol. 2002;40(11):4068-71. doi: 10.1128/JCM.40.11.4068-4071.2002. [PubMed: 12409376]. [PubMed Central: PMC139665].

13. Chan HL, Tsang SW, Leung NW, Tse CH, Hui Y, Tam JS, et al. Occult $\mathrm{HBV}$ infection in cryptogenic liver cirrhosis in an area with high prevalence of HBV infection. Am J Gastroenterol. 2002;97(5):1211-5. doi: 10.1111/j.1572-0241.2002.05706.x. [PubMed: 12014730].

14. Samal J, Kandpal M, Vivekanandan P. Molecular mechanisms underlying occult hepatitis B virus infection. Clin Microbiol Rev. 2012;25(1):142-
63. doi: 10.1128/CMR.00018-11. [PubMed: 22232374]. [PubMed Central: PMC3255968].

15. Raimondo G, Caccamo G, Filomia R, Pollicino T. Occult HBV infection. Semin Immunopathol. 2013;35(1):39-52. doi: 10.1007/s00281-012-0327-7. [PubMed: 22829332]. [PubMed Central: PMC3540364].

16. Sumera N. Occult hepatitis B virus Infection (OBI) and liver disease. PakJ Med Res. 2014;53(1):1-2.

17. Hu KQ. Occult hepatitis B virus infection and its clinical implications. J Viral Hepat. 2002;9(4):243-57. doi: 10.1046/j.1365-2893.2002.00344.x. [PubMed: 12081601].

18. Helaly GF, El Ghazzawi EF, Shawky SM, Farag FM. Occult hepatitis $\mathrm{B}$ virus infection among chronic hemodialysis patients in Alexandria, Egypt. J Infect Public Health. 2015;8(6):562-9. doi: 10.1016/j.jiph.2015.04.019. [PubMed: 26026236].

19. Schmeltzer P, Sherman KE. Occult hepatitis B: Clinical implications and treatment decisions. Dig Dis Sci. 2010;55(12):3328-35. doi: 10.1007/s10620-010-1413-0. [PubMed: 20927592]. [PubMed Central: PMC3001399].

20. Allain JP. Occult hepatitis B virus infection. Transfus Clin Biol. 2004;11(1):18-25. doi: 10.1016/j.tracli.2003.11.007. [PubMed: 14980545].

21. Ferrari TC, Xavier MA, Vidigal PV, Amaral NS, Diniz PA, Resende AP, et al. Occult hepatitis B virus infection in liver transplant patients in a Brazilian referral center. Braz J Med Biol Res. 2014;47(11):990-4. doi: 10.1590/1414-431X20143782. [PubMed: 25296362]. [PubMed Central: PMC4230290].

22. Hashemi SJ, Hajiani E, Masjedizadeh A, Makvandi M, Shayesteh AA, Alavinejad SP, et al. Occult hepatitis B infection in patients with cryptogenic liver cirrhosis in southwest of iran. Jundishapur J Microbiol. 2015;8(3). e16873. doi: 10.5812/jjm.16873. [PubMed: 25861432]. [PubMed Central: PMC4386076].

23. Alavian SM, Fallahian F, Lankarani KB. The changing epidemiology of viral hepatitis B in Iran.J Gastrointestin Liver Dis. 2007;16(4):403-6. [PubMed: 18193122].

24. Honarkar Z, Alavian SM, Samiee S, Saeedfar K, Zali MR. Occult hepatitis B among chronic liver disease patients. Saudi Med J. 2005;26(4):601-6. [PubMed: 15900369].

25. Anvari FA, Alavian SM, Norouzi M, Mahabadi M, Jazayeri SM. Prevalence and molecular analysis of occult hepatitis B virus infection isolated in a sample of cryptogenic cirrhosis patients in iran. Oman Med J. 2014;29(2):92-6. doi: 10.5001/omj.2014.23. [PubMed: 24715933]. [PubMed Central: PMC3976723].

26. Maheshwari A, Thuluvath PJ. Cryptogenic cirrhosis and NAFLD: Are they related? Am J Gastroenterol. 2006;101(3):664-8. doi: 10.1111/j.15720241.2006.00478.x. [PubMed: 16464222].

27. Alhababi F, Sallam TA, Tong CY. The significance of 'anti-HBc only' in the clinical virology laboratory. J Clin Virol. 2003;27(2):162-9. doi: 10.1016/S1386-6532(02)00171-3. [PubMed: 12829038].

28. Hou J, Liu Z, Gu F. Epidemiology and prevention of hepatitis B virus Infection. Int JMed Sci.2005;2(1):50-7. doi: 10.7150/ijms.2.50. [PubMed: 15968340]. [PubMed Central: PMC1142225].

29. Makvandi M. Update on occult hepatitis B virus infection. World J Gastroenterol. 2016;22(39):8720-34. doi: 10.3748/wjg.v22.i39.8720. [PubMed: 27818588]. [PubMed Central: PMC5075547].

30. Sutedja DS, Gow PJ, Hubscher SG, Elias E. Revealing the cause of cryptogenic cirrhosis by posttransplant liver biopsy. Transplant Proc. 2004;36(8):2334-7. doi: 10.1016/j.transproceed.2004.07.003. [PubMed: 15561241].

31. Duclos-Vallee JC, Yilmaz F, Johanet C, Roque-Afonso AM, Gigou M, Trichet C, et al. Could post-liver transplantation course be helpful for the diagnosis of so called cryptogenic cirrhosis? Clin Transplant. 2005;19(5):591-9. doi: 10.1111/j.1399-0012.2004.00323.x. [PubMed: 16146549].

32. Sakugawa H, Nakasone H, Nakayoshi T, Kawakami Y, Yamashiro T, Maeshiro T, et al. Clinical characteristics of patients with cryptogenic liver cirrhosis in Okinawa, Japan. Hepatogastroenterology. 2003;50(54):2005-8. [PubMed: 14696453]. 
33. Leite AB, Mattos AA, Mattos AZ, Coral GP, Evaldt S. Risk factors for nonalcoholic steatohepatitis in cryptogenic cirrhosis. Arq Gastroenterol. 2012;49(4):245-9. doi:10.1590/S0004-28032012000400003. [PubMed: 23329217].

34. Branco F, Mattos AA, Coral GP, Vanderborght B, Santos DE, Franca $\mathrm{P}$, et al. Occult hepatitis $\mathrm{B}$ virus infection in patients with chronic liver disease due to hepatitis $C$ virus and hepatocellular carcinoma in Brazil. Arq Gastroenterol. 2007;44(1):58-63. doi: 10.1590/S000428032007000100013. [PubMed: 17639185].

35. Xie M, Rao W, Yang T, Deng Y, Zheng H, Pan C, et al. Occult hepatitis B virus infection predicts de novo hepatitis B infection in patients with alcoholic cirrhosis after liver transplantation. Liver Int. 2015;35(3):897904. doi: 10.1111/liv.12567. [PubMed: 24750566].

36. Cholongitas E, Papatheodoridis GV, Burroughs AK. Liver grafts from anti-hepatitis B core positive donors: A systematic review. J Hepatol. 2010;52(2):272-9. doi: 10.1016/j.jhep.2009.11.009. [PubMed: 20034693].

37. Pollicino T, Squadrito G, Cerenzia G, Cacciola I, Raffa G, Craxi A, et al. Hepatitis B virus maintains its pro-oncogenic properties in the case of occult HBV infection. Gastroenterology. 2004;126(1):102-10. doi: 10.1053/j.gastro.2003.10.048. [PubMed: 14699492].

38. Brechot C. Pathogenesis of hepatitis B virus-related hepatocellular carcinoma: Old and new paradigms. Gastroenterology. 2004;127(5 Suppl 1):S56-61. doi: 10.1053/j.gastro.2004.09.016. [PubMed: 15508104].

39. Agarwal N, Naik S, Aggarwal R, Singh H, Somani SK, Kini D, et al. Occult hepatitis $B$ virus infection as a cause of cirrhosis of liver in a region with intermediate endemicity. Indian J Gastroenterol. 2003;22(4):12731. [PubMed: 12962434].

40. Kaviani MJ, Behbahani B, Mosallaii MJ, Sari-Aslani F, Taghavi SA. Occult hepatitis B virus infection and cryptogenic chronic hepatitis in an area with intermediate prevalence of HBV infection. World J Gastroenterol. 2006;12(31):5048-50. doi: 10.3748/wjg.v12.i31.5048. [PubMed: 16937504]. [PubMed Central: PMC4087411].

41. Heringlake S, Schutte A, Flemming P, Schmiegel W, Manns MP, Tillmann HL. Presumed cryptogenic liver disease in Germany: High prevalence of autoantibody-negative autoimmune hepatitis, low prevalence of NASH, no evidence for occult viral etiology. Z Gastroenterol. 2009;47(5):417-23. doi: 10.1055/s-0028-1109146. [PubMed: 19418409]. 